\title{
Judicial Review, Foreign Relations and Global Administrative Law
}

\section{The Administrative Function of Courts in Foreign Relations}

\author{
Angelo Jr. Golia
}

\section{INTRODUCTION: ADMINISTRATIVIZATION OF JURISDICTION AND JURIDIFICATION OF FOREIGN RELATIONS}

On 19 March 2019 the High Administrative Court (OVG) of North RhineWestphalia (Münster) issued a decision on the legality of the use of the Ramstein military air base ${ }^{1}$ which had been made available by Germany to the US for drone strikes in Yemen². Reversing the holding of the lower court, the OVG found that the measures taken by the German government did not suffice to fulfil its positive obligations arising from the right to life. Touching on crucial diplomatic relations, this decision is remarkable for at least two reasons. First, before starting the lawsuit before German courts, the plaintiffs had already sued the US government before American federal courts, but on appeal the DC District court decided that the alleged extrajudicial killings by drone strikes were a non-justiciable political question. Second, the OVG did not only find a violation of applicable constitutional and international law, but ordered also the German government to put into place measures to ensure the

1 Bin Ali Jaber v. Germany, Judgment, 19 March 2019, 4 A 1361/15. See Helmut Philipp Aust, 'USDrohneneinsätze und die grundrechtliche Schutzpflicht für das Recht auf Leben: "German exceptionalism"?' (2020) 75 Juristenzeitung 303; Leander Beinlich, 'Germany and its Involvement in the US Drone Programme before German Administrative Courts', EJIL: Talk!, April 8, 2019, www.ejiltalk.org/germany-and-its-involvement-in-the-us-droneprogramme-before-german-administrative-courts/, accessed September 30, 2020. The decision was quashed by the German Federal Administrative Court (BVerwG, Bin Ali Jaber v. Germany, Judgment, 25 November 2020, 6 C 7.19) in November 2020, as the present piece was already at the proof-editing stage. However, as pointed out by Helmut Aust and Thomas Kleinlein in the introduction to this volume, it remains the case that for both courts the question of whether international law permits armed drone missions in Yemen was not a political question, but rather a legal question, to be assessed by the judiciary.

$=$ The base was used for the relay of flight control data necessary to the drone strikes. 
legality of the use of the Ramstein base. Therefore, the OVG did not only review - unlike its US counterpart - the foreign policy of its own government, but also required it to manage/administer it in a different manner. This also means that, following the judgment, the German government was called to interact with the US in a way different from that originally planned, with a potential adverse impact on their otherwise (mostly) friendly relationship.

This case is exemplary of a general trend in contemporary western tradition systems towards the weakening of two fundamental dichotomies in their political-legal structures: that between domestic and foreign affairs; and that between judicial and executive/administrative power. Indeed, at least since the principle of separation of powers emerged as a distinctive feature of modern constitutionalism, western legal tradition has been built on the assumption that the public authorities performing executive/administrative functions and those performing judicial functions should be kept structurally distinct. $^{3}$ At the same time, liberal constitutions of the eighteenth and nineteenth centuries were based on a clear divide between internal and external sovereignty, ${ }^{4}$ dealing with foreign relations (FRs) only in a limited and ostensibly value-neutral way. That is why they generally did not impose substantive obligations to the political branches of government in the management of FRs. Interestingly, in Locke's construction of the separation of powers - which did not clearly distinguish between executive and judicial power - the federative power, ${ }^{5}$ what today is usually indicated as foreign relations power (FRP), was qualitatively different from the legislative and the executive: insofar as it could not be subject to prior legal norms, a judicial review over the exercise of federative power was conceptually inconceivable. ${ }^{6}$ More generally, the original theories of the rule of law and liberal constitutional models did not focus

3 This stark separation did not belong to either Locke's nor Montesquieu's theories: see Jenny S. Martinez, 'Horizontal Structuring', in Michel Rosenfeld and Andras Sajó (eds.), Oxford Handbook of Comparative Constitutional Law (Oxford: Oxford University Press, 2012), pp. 548-49; Christoph Möllers, The Three Branches (Oxford: Oxford University Press, 2013), pp. $16 \mathrm{ff}$.

4 The general assumption that Hobbes was actually the originator of the dichotomy between internal and external sovereignty is contested by Theodore Christov, 'Hobbes's Janus-Faced Sovereign', in David Dyzenhaus, Jacco Bomhoff and Thomas Poole (eds.), The Double-Facing Constitution (Cambridge: Cambridge University Press, 2019), pp. 94-120.

5 'The power of war and peace, leagues and alliances, and all the transactions with all persons and communities without the commonwealth.'

6 See John Locke, Two Treatises of Government (New Haven and London: Yale University Press, 2003), $\$ 147$, p. 165 . On the qualitative difference of the federative power see generally Thomas Poole, 'The Idea of the Federative', in David Dyzenhaus, Jacco Bomhoff and Thomas Poole (eds.), The Double-Facing Constitution (Cambridge: Cambridge University Press, 2019), pp. 54-93. 
on the relationship between a single State and other States, but almost exclusively on the internal sovereignty. ${ }^{7}$ As a consequence, they generally framed FRs as a sort of free zone where the rule of law did not apply, characterized by judicial deference and self-restraint, and therefore by a certain 'exceptionalism'. 8

Both normative and factual developments of the twentieth century affected the divide between domestic and foreign affairs. From a normative perspective, postwar constitutions have established more institutional constraints on FRP. ${ }^{9}$ At the same time, contemporary constitutionalism and international human rights and humanitarian law gave more relevance of the legal position of the individual, strengthening material constraints legal systems - especially in western tradition jurisdictions $-{ }^{10}$ and turning some cosmopolitan values into binding legal principles, that is, result-oriented norms to be potentially applied as standards of review also in the field of FRs." This might explain both the rise of foreign relations law (FRL) as a distinct field of legal studies and its persistently disputed

7 See Thomas Poole, 'The Constitution and Foreign Affairs' (2016) 69 Current Legal Problems 143 at $148 \mathrm{ff}$. (referring to a 'unilateral' constitutional model); Umberto Allegretti, 'Stato di diritto e divisione dei poteri nell'era dei conflitti asimmetrici' (2005) 11 Dir pubb 93 at 99-101.

8 The 'foreign affairs exceptionalism' implied in Locke's notion of federative power had a deep intellectual influence on American constitutionalism, especially through the work of William Blackstone, Commentaries, vol. I (Chicago: University of Chicago Press, 1979), p. 160 at 243. Classic formulations of such exceptionalism may be found in the US Supreme Court decisions Missouri v. Holland, 252 US 416 (1929); and United States v. Curtiss-Wright Export Corp, 299 US 304 (1936). See generally David Dyzenhaus, 'Hobbes on the International Rule of Law' (2014) 28 Ethics \& International Affairs 53; Thomas M. Franck, Political Questions/Judicial Answers. Does the Rule of Law Apply to Foreign Affairs? (Princeton: Princeton University Press, 1992), pp. 10-30 (for the influence of British doctrine of royal prerogative on the practice of judicial abdication in the US); J. Richard Broughton, 'Judicializing Federative Power' (2006) 11 Texas Review of Law \& Politics 283; Stephen Breyer, The Court and the World. American Law and the New Global Realities (New York: Vintage, 2015), pp. $15 \mathrm{ff}$.

9 See Luzius Wildhaber, Treaty-Making Power and Constitution. An International and Comparative Study (Basel-Stuttgart: Helbing \& Lichtenhahn, 1971); Jenny S. Martinez, 'The Constitutional Allocation of Executive and Legislative Power Over Foreign Affairs: A Survey', in Curtis A. Bradley (ed.), Oxford Handbook of Comparative Foreign Relations Law (Oxford: Oxford University Press, 2019), pp. 97-114.

10 On the internationalization/humanization of public law see Thomas Buergenthal, 'Modern Constitutions and Human Rights Treaties' (1998) 36 Columbia Journal of Transnational Law 211; Chang Wen-Chen and Yeh Jiunn-Rong, 'Internationalization of Constitutional Law', in Michel Rosenfeld and Andras Sajó (eds.), Oxford Handbook of Comparative Constitutional Law (Oxford: Oxford University Press, 2012), pp. 1165-84; Karen Knop, 'The Spectre of Comity', in David Dyzenhaus, Jacco Bomhoff and Thomas Poole (eds.), The DoubleFacing Constitution (Cambridge: Cambridge University Press, 2019), pp. 177-210.

${ }^{11}$ See generally Franck, Political Questions/Judicial Answers, pp. 61 ff.; Deborah N. Pearlstein, 'After Deference: Formalizing the Judicial Power for Foreign Relations Law' (2011) 159 University of Pennsylvania Law Review 783; Ganesh Sitaraman and Ingrid Wuerth, "The 
disciplinary location. ${ }^{12}$ Indeed, constitutional and international law together changed the normative relationship between law and FRs, ${ }^{13}$ traditionally based on a strict interpretation of the separation of powers and on axiological neutrality. ${ }^{14}$ From a more factual perspective, globalization processes established deep and unprecedented interdependencies among individuals, polities and systems at global level, ${ }^{15}$ piercing national-political boundaries and therefore weakening the factual bases underpinning the domestic/foreign dichotomy.

Turning to the divide between judicial and executive/administrative power, today even Kelsen would be surprised to see how the prediction he made in the early twentieth century while discussing the theoretical foundations of constitutional adjudication - the end of the 'opposition' between judicial and executive power $-{ }^{16}$ has come close to reality. Following the rise of principled (i.e. result-oriented $)^{17}$ norms and relative indeterminacy in contemporary

Normalization of Foreign Relations Law' (2015) 128 Harvard Law Review 1897; Poole, 'The Constitution and Foreign Affairs'.

12 For the debate concerning the interaction between public international law and FRL see the chapter by Curtis A. Bradley, 'Final Reflections', in this volume; Curtis A. Bradley, 'What Is Foreign Relations Law?', in Curtis A. Bradley (ed.), Oxford Handbook of Comparative Foreign Relations Law (Oxford: Oxford University Press, 2019), pp. 8-13; and Helmut Philipp Aust and Thomas Kleinlein, 'Introduction', this volume, arguing that the 'hybridity' between domestic (public) law and public international law is an effect rather than a characteristic of FRL.

13 See Poole, 'The Constitution and Foreign Affairs', $148 \mathrm{ff}$. (referring to a 'reflexive' or 'mutually constitutive' constitutional model). More generally see Jean-Bernard Auby, Globalisation, Law and the State (Oxford: Hart, 2017), pp. 80 ff.

14 This may also be read as the latest stage of a more general process, started with modernity, of formalization of politics by law. See Chris Thornhill, A Sociology of Constitutions: Constitutions and State Legitimacy in Historical-Sociological Perspective (Cambridge: Cambridge University Press, 2011); Torbjörn Vallinder, 'The Judicialization of Politics. A World-Wide Phenomenon: Introduction' (1994) 15 IPSR 91; Ran Hirschl, 'The Judicialization of Mega-Politics and the Rise of Political Courts' (2008) 11 Annual Review of Political Science 93 .

15 See famously Anthony Giddens, The Consequences of Modernity (Cambridge: Polity, 1990), pp. $64 \mathrm{ff}$.

16 See Hans Kelsen, 'La garantie juridictionnelle de la constitution' (1928) 45 Revue du droit public et de la science politique en France et à l'étranger 197 at 212-14. At the time Kelsen wrote, public law theory was still influenced by assumptions typical of the nineteenth century administrative state, framing executives as possessing autonomous legitimation: in that context, the distinction between jurisdictional and executive/administrative functions was traditionally linked to the fact that only the exercise of the former was based on legal rules. Rejecting this criterion, Kelsen argued that the relationship of administrative/executive bodies towards law did not qualitatively differ from that of judicial bodies, especially when it comes to the norms of 'higher level'. Rather, the only real distinction lied in the different modes of organization of tribunals and executive bodies, difference that he predicted would come to an end.

17 See Robert Alexy, A Theory of Constitutional Rights (Oxford: Oxford University Press, 200z), pp. $47-49$, and his conception of principles as result-oriented norms, i.e. norms containing 'optimisation commands'. 
legal systems, ${ }^{18}$ and the spread of judicial review mechanisms, judicial practice has progressively internalized consequentialist and teleological approaches. ${ }^{19}$ Next to normative inputs, courts are more and more conditioned by the (expected) output of their decisions, and accommodate them to future-oriented purposes set by law in specific regulatory fields, as general or indeterminate as they may appear. Often based on balancing/proportionality techniques, domestic and international courts turn (their perception of) social expectations and policy goals, positivized in legislative, constitutional or international norms, into decisions aimed at solving and/or managing concrete issues on an ongoing basis, thus performing de facto executive/administrative functions. Therefore, rather than simple external reviewers, they increasingly act as internal participants in administrative functions. In the context of global governance, such 'administrativization' of the judicial function places courts in the broader set of global regulators, ${ }^{20}$ thus contributing to the development and implementation of rules of coexistence, collision and cooperation among involved systems. ${ }^{21}$

This chapter investigates the connection between the expanding 'administrative' functions of courts and the ongoing normalization (i.e. juridification/ judicialization) of FRs. ${ }^{22}$ To that purpose, it resorts to the analytical tools of the 'global administrative law' (GAL) approach, and argues that there is a factual trend towards what may be seen as a 'global administrative law of foreign relations', that is, a transnational legal language erratically but increasingly

Gunther Teubner, “'And God Laughed ...” Indeterminacy, Self-Reference and Paradox in Law' (2011) 12 German Law Journal 376; Inger Johanne Sand, 'Changing Forms of Governance and the Role of Law', ARENA WP No. oo/14, www.sv.uio.no/arena/english/research/publications/ arena-working-papers/1994-2000/2000/wpoo_14.htm, accessed September 30, 2020.

19 See Neil MacCormick, 'Argumentation and Interpretation in Law' (1993) 6 Ratio Juris 16; Gunther Teubner, 'Altera Pars Audiatur: Law in the Collision of Discourses', in Richard Rawlings (ed.), Law, Society and Economy (Oxford: Oxford University Press, 1997), p. 149 at 167; Klaus Mathis, 'Consequentialism in Law', in Klaus Mathis (ed.), Efficiency, Sustainability, and Justice to Future Generations (Berlin: Springer, 2012), pp. 3-29.

2o See Sabino Cassese, The Global Polity. Global Dimensions of Democracy and the Rule of Law (Sevilla: Global Law Press, 2012); Elisa D’Alterio, 'Judicial Regulation in the Global Space', in Sabino Cassese, Research Handbook on Global Administrative Law (Cheltenahm: Elgar, 2016), pp. $314 \mathrm{ff}$. On the link between proportionality-based reasoning and 'administratization' of constitutional law and constitutional adjudication see Moshe Cohen-Eliya and Iddo Porat, 'Proportionality and the Culture of Justification' (2011) 59 American Journal of Comparative Law 463 , pp. $487 \mathrm{ff}$.

21 See Anne-Marie Slaughter, A New World Order (Princeton: Princeton University Press, 2004), pp. 51-61.

22 See Sitaraman and Wuerth, 'The Normalization of Foreign Relations Law'; Carlos M. Vasquez, 'The Abiding Exceptionalism of Foreign Relations Doctrine' (2015) 128 Harvard Law Review Forum 305. 
developed by courts in different jurisdictions, aimed at concretely managing issues falling within the scope of FRs. More specifically, the GAL approach is used, firstly, to conceptualize the function performed by courts applying FRL in the context of the increased interdependence driven by the processes of globalization and global governance. This means that, as courts increasingly participate in the 'administration' of FRs, an administrative conception can be added to and, to a certain extent, overlaps with other conceptions ${ }^{23}$ of FRL. From this perspective, the trend towards the judicial 'administration' of FRs could be seen as the ultimate form of the - admittedly precarious and reversible-normalization of FRL. Secondly, the GAL approach is here used to categorize judicial rulings, according to the type of norms they implement or develop in the context of FRL. Here, it is possible to conceptually distinguish between norms and/or standards implemented or developed in relation to the FRs conduct of the political branches of the jurisdiction to which a given court belongs ('review norms'); and norms and/or standards implemented or developed to manage interactions with other jurisdictions or legal systems affecting FRs ('interaction norms').

Section II briefly recalls the main features of FRL (subsection II.A) and GAL (subsection II.B), mapping the analytical bases of the chapter, their conceptual assumptions, and the main challenges they face. Based on an a-systematic survey, Section III outlines a tentative taxonomy of the forms that the judicial practice takes in developing an embryonic 'global administrative law of foreign relations.' In particular, subsection III.A focuses on the 'review norms', while subsection III.B on the 'interaction norms'. Section IV concludes, summarizing the core claims and highlighting, from a more normative perspective, the potential risks of the administrativization of FRs, which may also cast doubts on the general value of GAL as a normative endeavor.

\section{BRINGING TOGETHER FRL AND GAL}

\section{A The Struggles of FRL with its Scope, Sources and Functions}

FRL intersects two axes of constitutional legal theory: the relationship between domestic law and international/transnational legal systems; ${ }^{24}$ and

23 See Campbell McLachlan, 'Five Conceptions of the Functions of Foreign Relations Law', in Curtis A. Bradley (ed.), Oxford Handbook of Comparative Foreign Relations Law (Oxford: Oxford University Press, 2019), pp. 21 ff.

24 See Anne Peters, 'Foreign Relations Law and Global Constitutionalism' (2017) 111 AJIL Unbound 331. 
that between judicial and political branches in legal systems characterized by the constitutionalization of value choices. ${ }^{25}$ However, although it is by now relatively well-established as a field of studies (at least in common law jurisdictions), FRL still struggles with some foundational issues, ${ }^{26}$ concerning its scope, sources and functions.

Concerning its scope, at least two conceptions of FRL may be individuated. The first one, based on a strict dichotomy domestic/foreign, limits FRL to three macro-areas: treaty-making, -development and -termination; international and supranational integration; and use of military force. ${ }^{27}$ A broader conception, based on a functional understanding of FRL, focuses on all the legal norms affecting the relations of a nation with the rest of the world. Under this broader conception, FRL would for example include the conflict of laws of each nation, ${ }^{28}$ and in some cases even fields normally regarded as purely internal. A US Supreme Court decision concerning the interpretation of federal copyright law ${ }^{29}$ may matter to manufacturers and consumers both in the US and throughout the world, with economic impacts worth billions, and potentially generating significant diplomatic frictions. ${ }^{30}$ Likewise, a judgment of the German Federal Constitutional Court (BVerfG), holding that a specific statutory design for the surveillance powers of intelligence agencies violate the Basic Law, and forbidding the transfer of data thus obtained to other intelligence services, ${ }^{31}$ may undermine the diplomatic position of the German government. Similarly, constitutional provisions and the related judicial rulings concerning public ownership of natural resources and property rights of corporations constitute examples of norms functionally falling withing FRL - especially from a 'peripheral perspective'. ${ }^{32}$ In all these cases constitutional courts inevitably decide also on FRs issues, as in the age of globalization FRs are virtually everywhere. Therefore, the struggles of FRL

25 See in recent scholarship Möllers, The Three Branches.

26 See McLachlan, 'Five Conceptions of the Functions of Foreign Relations Law', p. 20.

27 See e.g. Thomas Giegerich, 'Foreign Relations Law', in Rüdiger Wolfrum (ed.), Max Planck Encyclopedia of Public International Law, vol. IV (Oxford: Oxford University Press, 2011), p. 178 at 183 .

28 See William S. Dodge, 'International Comity in Comparative Perspective', in Curtis A. Bradley (ed.), Oxford Handbook of Comparative Foreign Relations Law (Oxford: Oxford University Press, 2019), pp. 701 ff.; and Restatement of the Law Fourth, The Foreign Relations Law of the United States (Philadelphia: ALI, 2018), pp. $148 \mathrm{ff}$ and $303 \mathrm{ff}$.

29 See Kirtsaeng v. John Wiley \& Sons, Inc., 568 US 519 (2013).

3० See Breyer, The Court and the World, pp. 124-31.

31 See BVerfG, 19 May 2020, 1 BvR 2835/17 - BND.

32 See Michael Riegner, 'Comparative Foreign Relations Law between Center and Periphery', in this volume. 
scholarship with the definition of its own analytical scope derive also from the difficulty to be coextensive with its factual scope. ${ }^{33}$

Regarding its sources, FRL has been traditionally conceived as a branch of domestic systems, ${ }^{34}$ namely of their constitutional and administrative law. ${ }^{35}$ However, following the normative developments occurred during the twentieth century, FRL has progressively come to include international law, ${ }^{6}$ to the extent this latter applies to a specific domestic jurisdiction, or imposes on States a certain conduct in the management of their FRs, or directly regulates the conduct of individuals. Importantly, the influence of international law sources contributes to making FRL at least in part 'transnational', insofar as courts in different jurisdictions, which apply the same rules of international law or decide on similar issues concerning FRs, increasingly develop comparable and/or equivalent - albeit not identical - standards of adjudication, ${ }^{37}$ also through reciprocal influence and cross-fertilization. ${ }^{3}$

This last aspect is linked to the functions attributed to FRL. Campbell McLachlan has listed five conceptions of the functions performed by FRL, namely the exclusionary, the internationalist, the constitutional, the diplomatic and the allocative. ${ }^{39}$ While not necessarily mutually exclusive, these conceptions have different ideological roots, and potentially result in conflicting implementations by institutional actors, especially courts. Put differently: in applying FRL or in adjudicating issues related to FRs, judicial bodies may develop different understandings of their own role and the results to pursue, also depending on the underlying function attributed to FRL. However, none of these conceptions as such captures the idea that FRL has come to provide

33 See Anne Peters, 'Military Operations Abroad under the German Basic Law', in Curtis A. Bradley (ed.), Oxford Handbook of Comparative Foreign Relations Law (Oxford: Oxford University Press, 2019), p. 8o9.

34 See Giegerich, 'Foreign Relations Law', p. 178.

35 See Jean Galbraith, 'From Treaties to International Commitments: The Changing Landscape of Foreign Relations Law' (2017) 64 University of Chicago Law Review 167, at $1684-97$.

${ }^{6}$ On the 'double-facing' nature of FRL see McLachlan, 'Five Conceptions of the Functions of Foreign Relations Law', p. 2; and David Dyzenhaus, 'The Janus-Faced Constitution', in David Dyzenhaus, Jacco Bomhoff and Thomas Poole (eds.), The Double-Facing Constitution (Cambridge: Cambridge University Press, 2019), pp. 17-53.

37 See Bradley, 'Final Reflections', in this volume and, in deeper detail, Anthea Roberts et al. (eds.), Comparative International Law (Oxford: Oxford University Press, 2018).

$3^{8}$ See generally Gregory Shaffer and Carlos Coye, 'From International Law to Jessup's Transnational Law, From Transnational Law to Transnational Legal Orders', UC Irvine School of Law Research Paper No. 2017-02.

39 See again McLachlan, 'Five Conceptions of the Functions of Foreign Relations Law'. 
concrete legal standards - potentially justiciable by courts - to 'manage' FRs on an ongoing basis.

In the light of such struggles, it seems that no single approach accounts in a comprehensive manner for some key elements of FRL, namely the mismatch between its analytical and factual scope; its 'transnationality'; its potentially 'administrative' function; and, finally, the active - be it unifying or fragmenting - role played by judicial bodies in that context.

\section{B GAL As an Analytical Approach to FRL}

Giving an accurate idea of GAL in few words is not easy. It has emerged together with other approaches in the galaxy of global law and postnational constitutionalism, ${ }^{4}$ and it does not indicate a full-fledged legal system in a traditional sense..$^{41}$ Rather, it can be broken down into two main parts.

Firstly, GAL stands as an analytical/descriptive tool, referring to a factual ${ }^{42}$ trend whereby a set of procedural and substantive norms - inter alia review, transparency, reason-giving, participation, audiatur altera pars, legal accountability and liability of administrative authority - has been increasingly developed and implemented, either formally or informally, by 'global administrative bodies' (GABs) all around the world and at different governance levels, including the domestic one. GAL focuses on the 'mechanisms, principles, practices, and supporting social understandings that promote or otherwise affect the accountability of global administrative bodies'. ${ }^{43}$ It highlights that, when confronted with functionally differentiated issues of global concern (corruption, competition, banking supervision, terrorism, food safety, etc.), GABs of different jurisdictions and governance levels increasingly interact, often working as (either formal or informal) transnational networks. From this standpoint, GAL claims that 'much of the global governance can be understood in administrative terms, as global administration that operates in a "global administrative space" ... in which the strict dichotomy between domestic and international has largely broken

$4^{\circ}$ Although it is not possible to discuss its conceptual genealogy here, see Benedict Kingsbury, Nico Krisch, and Richard B. Stewart, 'The Emergence of Global Administrative Law' (2005) 68 Law and Contemporary Problems 15; Sabino Cassese, 'Administrative Law Without the State? The Challenge of Global Regulation' (2005) 37 NYU Journal of International Law and Politics 663; Cassese, Research Handbook.

${ }^{4}$ See however Benedict Kingsbury, 'The Concept of "Law" in Global Administrative Law' (2009) 20 EJIL 23.

42 See Lorenzo Casini, 'Global Administrative Law Scholarship', in Sabino Cassese, Research Handbook on Global Administrative Law (Cheltenham: Elgar, 2016), p. 554.

43 Kingsbury, Krisch, and Stewart, 'The Emergence of Global Administrative Law', 17. 
down'. ${ }^{4}$ Therefore, the label 'GAL' refers to an emerging form of transnational law, whose norms are implemented and developed by sub- and non-state administrative institutions, often with little or no involvement of political branches of governments.

Secondly, GAL embodies the normative stance of a scholarly movement towards such practices. In other words, the GAL approach does not only outline the factual implementation of a certain set of norms by administrative bodies, but also supports their spread and strengthening. It also argues that these norms and networked modes of action help to order the structures of global governance and achieve results in fields of common concern, by also strengthening their legitimacy and cooperation, and decreasing conflicts and inconsistencies among involved actors/systems. From this perspective, GABs would be also incentivized to act as transnational networks. Overall, the GAL approach claims to retains a soft normative value, aiming to bridge a relatively little gap between an 'Is' and an 'Ought' at global level, by expanding guarantees in administrative action, in fields where they have not been established yet. By these means, the GAL approach is - or claims to be - less ambitious than other 'constitutionalist' approaches to global law, ${ }^{45}$ as it does not engage directly with the issue of unitary axiological framework(s) and global democracy.

The GAL approach deals with courts in two different yet linked ways. ${ }^{4}$ First, they are regarded as reviewing bodies, checking the respect by GABs of the norms aimed at keeping them accountable and increasing their legitimacy. Therefore, courts implement and develop review norms on administrative action. Secondly, they are regarded as GABs themselves, especially when exercising substituting functions or working as transnational networks. In this latter case, the standards developed or implemented by courts often take the form of 'interaction norms' (margin-of-appreciation; Solange-like doctrines; subsidiarity; deference/comity doctrines), and are generated by courts to manage actual or virtual clashes among the systems where they operate respectively. ${ }^{47}$ One of the merits of GAL as an analytical tool has been to

44 Nico Krisch and Benedict Kingsbury, 'Introduction: Global Governance and Global Administrative Law in the International Legal Order' (2006) 17 EJIL 1.

45 See Nico Krisch, 'Global Administrative Law and the Constitutional Ambition', in Petra Dobner and Martin Loughlin (eds.), The Twilight of Constitutionalism? (Oxford: Oxford University Press, 2010), pp. 245-66.

$4^{6}$ For more detailed accounts see D'Alterio, 'Judicial Regulation in the Global Space', pp. $314 \mathrm{ff}$; and Eyal Benvenisti and George W. Downs, Between Fragmentation and Democracy. The Role of National and International Courts (Cambridge: Cambridge University Press, 2017).

47 See Sabino Cassese, I tribunali di Babele. I giudici alla ricerca di un nuovo ordine globale (Rome: Donzelli, 2009). 
highlight that, whether they act as reviewers of the action of GABs or as GABs themselves, courts take part of the regulation/administration of global governance. ${ }^{4^{8}}$ Another analytical contribution of GAL is to read the interactions and reciprocal influences among courts as networks. Indeed, judicial networks, just like other information, harmonization and enforcement networks, ${ }^{49}$ may promote convergence, compliance and cooperation among involved systems, and they are called upon to manage clashes emerging from globalization processes..$^{50}$

In the light of these considerations, the GAL approach may provide a useful - although not exclusive - analytical/descriptive framework, at the same time accounting for the elusive scope of FRL, its 'transnationality', its 'administrative' function, and the role played by courts in managing coordination and/or fragmentation among systems. In other words, the GAL approach constitutes a viable tool to frame and understand two major tensions underlying FRL: that between its still somehow persistent 'exceptionalism' and ongoing/erratic process of normalization, where the aspiration to manage even FRs according to material legal standards meets the obstacles of the Realpolitik; and that between its domestic and international dimensions, where the aspiration to provide global legal standards meets the obstacles of different sources of legitimation and modes of lawmaking. The GAL approach crosscuts these tensions and may potentially offer a useful conceptual framework. Building on this core insight, the next section brings the argument further and, based on the GAL framework, outlines a tentative taxonomy of the decisions of courts 'administering' FRs.

\section{A (TENTATIVE) TAXONOMY OF A 'GLOBAL ADMINISTRATIVE LAW OF FRS'}

Drawing a clear-cut taxonomy of the decisions taken by domestic courts in FRs matters is problematic, considering the institutional and procedural variances among different systems of judicial review. However, based on the GAL

$4^{8}$ See Cassese, I tribunali di Babele; Elisa D’Alterio, 'From Judicial Comity to Legal Comity: A Judicial Solution to Global Disorder?' (2011) 9 ICON 394; D'Alterio, 'Judicial Regulation in the Global Space', explicitly referring to courts as 'GAL regulators'.

49 For these categorizations see again Slaughter, A New World Order, pp. 51-61.

50 The persisting significant differences between administrative and judicial networks cannot be explored here, but see further Alexander Somek, 'Administration without Sovereignty', in Petra Dobner and Martin Loughlin, The Twilight of Constitutionalism? (Oxford: Oxford University Press, 2010), pp. 267-87; Christoph Möllers, 'Constitutional Foundations of Global Administration', in Sabino Cassese (ed.), Research Handbook on Global Administrative Law (Cheltenham: Elgar, 2016), pp. $114 \mathrm{ff}$. 
TABLE 7.1 Taxonomy of the Judicial Administration of Foreign Relations

\begin{tabular}{|c|c|c|}
\hline & $\begin{array}{l}\text { REVIEW OF FRS ACTS/CON- } \\
\text { DUCTS ('REVIEW NORMS') }\end{array}$ & $\begin{array}{l}\text { INTERACTION WITH OTHER } \\
\text { SYSTEMS IN FRS ('INTER- } \\
\text { ACTION NORMS') }\end{array}$ \\
\hline $\begin{array}{l}\text { JUDICIAL } \\
\text { PROCEDURE } \\
\text { GROUNDS }\end{array}$ & $\begin{array}{l}\text { - Access/standing } \\
\text { - Deference to executive's } \\
\text { interpretation/findings } \\
\text { - Justiciability doctrines } \\
\text { - } \quad(\ldots)\end{array}$ & $\begin{array}{l}\text { - International comity } \\
\text { - } \text { Extraterritoriality } \\
\text { - } \\
\text { Self-execution doctrines }\end{array}$ \\
\hline $\begin{array}{c}\text { SUBSTANTIVE } \\
\text { GROUNDS }\end{array}$ & $\begin{array}{l}\text { - Legality/constitutionality } \\
\text { - Human rights } \\
\text { - Proportionality/reasonableness } \\
\text { - } \\
\text { - }(\ldots \text { articipation/representation }\end{array}$ & $\begin{array}{l}\text { - Evaluation of other systems' } \\
\text { respect of human rights } \\
\text { - }(\ldots)\end{array}$ \\
\hline
\end{tabular}

framework, ${ }^{51}$ one may distinguish between (1) norms involving the application of certain standards of review on FRs acts, or of acts otherwise affecting FRs ('review norms'); (2) norms affecting the coordination/cooperation with other systems in FRs matters ('interaction norms'). Both categories may in turn be subcategorized, based on the procedural or substantive grounds. Such taxonomy is summarized above in Table 7.1.

To be sure, these categories should be seen only as a general descriptive account of the way courts generally frame the arguments underpinning their decisions in FRs matters, and may in fact overlap. For example, reasonableness/proportionality arguments are categorized sub the 'review norms' category, as they are mostly used as a benchmark to review domestic acts, but may often explicitly enter into considerations related to comity. Similarly, decisions based on justiciability doctrines (e.g. the British 'foreign act of State') may also give rise to interaction norms. More generally, such taxonomy does not aspire to establish strong normative divides, especially considering that the same decision may often generate uno actu both review and interaction norms.

\section{A Review Norms}

The first category, comprising the review norms implemented and/or developed on the issue as to whether to decide, includes rules on the access/standing of

51 See above Section II.B. 
private parties, the deference towards executive (either on the interpretation of relevant law or on factual findings), the justiciability of the question, etc. In this field, for the last decades domestic judicial practice has been heading - slowly, contradictorily, but constantly - towards the expansion of the courts' competence to adjudicate FRs issues, both in common law and in civil law jurisdictions. More importantly, courts seem increasingly to be reducing the use and scope of 'exceptional' doctrines of nonjusticiability (such as the US political question doctrine) and/or of deference to executives' interpretations/findings, often under the influence of international human rights law. ${ }^{52}$ Indeed, even when they accord such deference, they increasingly give their own legal justifications as to the reasons for doing so (e.g. executive expertise).

In civil law jurisdictions, Germany is probably the most prominent example of rejection of doctrines of judicial abdication in FRs matters, even for cases involving the deployment of military force. ${ }^{53}$ Helped by their specific cultural and institutional environment, since at least the 1954 Status of the Saar case, ${ }^{54}$ through the 1983 Pershing II case, ${ }^{55}$ up to the decision of the OVG Münster on the use of the Ramstein base, German courts have consistently rejected doctrines of intrinsic nonjusticiability,,$^{56}$ and rather tend slightly to lower the intensity of scrutiny of the merits case. ${ }^{57}$

52 See e.g. ECtHR Chevrol v. France (App. No. 49636/99), Judgment (Second Section), February 13, 2003, https://hudoc.ECHR.coe.int/app/conversion/pdf/?library=ECHR\&i $\mathrm{d}=001-60941 \&$ filename $=001-60941$.pdf\&TID=thkbhnilzk, accessed September 30, 2020.

53 On the contrary, French and Italian (mainly administrative) courts keep on applying doctrines of judicial abstention (acte de gouvernement, atto politico) in cases involving the use of military force. See Conseil d'Etat, No. 255905, 10 April 2003; No. 292539, 17 April 2006; No. 321470, 15 October 2008; and Cons St, 11 May 1966, No. 344; Cons St, 3 August 2000, No. 530; Cass, 5 June 2002, No. 8157-Markovic; Cons St, No. 3992, 29 July 2008; Trib Rome, Società Fincantieri, 10 October 1991. See Moncef Kdhir, 'La théorie de l'acte de gouvernement dans la jurisprudence du Conseil d'Etat relative aux relations internationales de la France à l'épreuve du droit international' (2003) 4 JDI 1059; Natalino Ronzitti, 'Azioni belliche e risarcimento del danno' (2002) 85 Rivista di dritto internazionale 682; and Daniele Amoroso, 'A Fresh Look at the Issue of NonJusticiability of Defence and Foreign Affairs' (2010) 23 Leiden Journal of International Law 933.

55 BVerfGE 66, 39 - Nachrüstung, where the German Federal Constitutional Court was called to decide whether the government's authorization to the installation of nuclear missiles on German territory was compatible with international law. See also a similar decision in the UK, Hutchinson v. Newbury Magistrates Court [2000] EWHC QB 61; and, in Italy, Trib Ragusa, Barker e altri, 14 April 1984, (1985) 108 Foro italiano 21 (alluding, however, to the impossibility to adjudicate the question on the merits).

${ }_{56}$ Whereby a judge recognizes that an applicable legal standard to decide the issue would be virtually available but abstains from adjudicating it anyway.

57 See Franck, Political Questions//udicial Answers, pp. 107-25; Peters, 'Military Operations Abroad under the German Basic Law'. 
Contrary to some scholarly suggestions, ${ }^{58}$ even common law jurisdictions, where the influence of 'foreign affairs exceptionalism' is traditionally stronger, seem to participate in this trend. Importantly, in its most recent case law the US Supreme Court has increasingly rejected the use of the so-called Chevron approach in FRs matters. Such approach, intrinsically linked to the autonomous political legitimation of the executive branch in US government, compels federal courts to defer to a federal agency's interpretation of an ambiguous statute that Congress delegated to the agency to administer, and results in an almost exclusive abdication to government's agencies in interpreting the statutes. ${ }^{59}$ Similarly, US federal courts are gradually reducing the application of the political question doctrine, even in key FRs cases such as Zivotofsky, ${ }^{60}$ the Guantanamo cases ${ }^{61}$ and, more recently, Al Shimari, ${ }^{62}$ concerning alleged acts of torture committed by a private military contractor's employees towards Abu Ghraib prisoners, which vacated the lower court's dismissal based on the political question doctrine.

Other examples of this trend may be found in the case law of the Israeli Supreme Court starting from the beginning of the 1980 , ${ }^{63}$ in the practice of the Canadian Supreme Court, ${ }^{64}$ as well as in India, ${ }^{65} \mathrm{UK}^{66}$

$5^{8}$ Eric A. Posner and Cass R. Sunstein, 'Chevronizing Foreign Relations Law' (2006) 116 Yale Law Journal 1170.

59 See Nada Mourtada-Sabbah and Bruce E. Cain (eds.), The Political Question Doctrine and the Supreme Court of the United States (Lanham: Lexington, 2007); Sitaraman and Wuerth, 'The Normalization of Foreign Relations Law'; Breyer, The Court and the World, pp. 65-87.

60 Zivotofsky v. Clinton, 566 US 189 (2012), holding that a dispute over the regulation of passports was not a political question and thus resolvable by the courts.

61 Rasul, 542 US 466 (2004); Hamdi, 542 US 507 (2004); Hamdan, 548 US 557 (2006); Boumediene, 553 US 723 (2008).

62 Al Shimari v. CACI Premier Tech, Inc (Al Shimari IV), 840 F.3d 147, 151 (4th Cir. 2016).

63 See e.g. Segal v. Minister of Interior, HCJ 217/8o; Shiran v. Broadcasting Authority, HCJ 1/81; Baransa v. Commander of Central Command, HCJ, 554/81; Ressler v. Minister of Defense, HCJ 910/86, Hilman v. Minister of Internal Security, HCJ, 3123/99; Adala v. Commander of Central Command, HCJ 3799/o2, affirming the justiciability of questions related to military operations, in some instances even issuing preliminary orders to stop them. See Menachem Mautner, Law and the Culture of Israel (Oxford: Oxford University Press, 2011), pp. $61 \mathrm{ff}$.

64 See Operation Dismantle $[1985]$ i SCR 441, rejecting on the merits the challenge against the executive for allowing the US government to test cruise missiles over Canadian territory, but dismissing the 'political question' doctrine; and, similarly, Canada (Prime Minister) v. Khadr [2010] 1 SCR 44, concerning the modalities Canada should respond to the violation of a Canadian citizen's rights held in at the Guantanamo Bay detention facility.

65 See the evolution from State of Rajasthan v. Union of India [1977] (3) SCC 5, to Bommai v. Union of India [1994] 2 SCR 644.

66 Historically, UK courts have practiced a high degree of self-restraint towards the royal prerogative, especially in foreign affairs: see Frederick Alexander Mann, Foreign Affairs in English Courts (Oxford: Clarendon, 1986); Nigel D. White, Democracy Goes to War (Oxford: 
South Africa ${ }^{67}$ and even Russia. ${ }^{68}$ More generally, when courts declare inadmissible a question related to FRs, they increasingly resort to the 'ordinary' tools provided by judicial procedure, such as standing requirements, although even the evolutive interpretation of these latter seems increasingly to permit a greater access of private individuals to litigate FRs issues. ${ }^{69}$ In particular, the comparison between Germany and the US shows that, while the respective practice still differs as for the underlying legal culture and the concrete results, there is a sort of progressive alignment as for the restriction of 'exceptional' doctrines of judicial abdication.

These insights support the claim that the area of judicial reach over FRs is expanding. Such 'normalization' is a necessary precondition for claiming that the management of FRs can be conceived in terms of (co-)administration by courts. Indeed, insofar as judicial bodies increasingly address the merits of FRs cases, or declare them inadmissible based on ordinary procedural standards, they apply the same norms as for any other executive action. At the same time, the possibilities for courts to adjudicate and even 'administer' FRs issues grow.

Concerning the legal standards used on the merits, that is, the norms concerning how to decide on FRs issues, it is also possible to identify an expanding trend. Indeed, national courts - in the different ways permitted by their respective domestic law - increasingly use the same substantive criteria of evaluation as for ordinary domestic issues. This trend, which varies in context and intensity, does not concern only the application of constitutional/legislative norms specifically related to FRs (e.g., the content of an

Oxford University Press, 2009), pp. 283-94. However, see CCSU v. Minister for the Civil Service [1984] UKHL 9, holding that prerogative powers are as susceptible to judicial review as statutory powers; and, more recently, Belhaj \& Rahmatullah (No 1) v. Straw E Ors [2017] UKSC $_{3}$, ruling that sued officials had not shown any entitlement to rely on the doctrine of the Crown act of state so as to defeat the claims brought against them. See Eirik Bjorge and Cameron Miles, 'Crown and Foreign Acts of State before English Courts: Rahmatullah, Belhaj, and the Separation of Powers', in Curtis A. Bradley (ed.), Oxford Handbook of Comparative Foreign Relations Law (Oxford: Oxford University Press, 2019), pp. 715-32.

67 See Kaunda and Others v. the President of the Republic of South Africa and Others 2005 (4) SA 235 (CC), already holding that courts are entitled to review decisions of the executive in the exercise of its mandate in FRs. See the chapter by Dire Tladi, 'A Constitution Made for Mandela, a Constitutional Jurisprudence Developed for Zuma', this volume.

68 See the Chechnya judgment of 31 July 1995, where the Constitutional court heard petitions by opposition members of the Duma, challenging the constitutionality of three presidential decrees ordering the invasion of Chechnya. The Russian case is recalled next to common law jurisdictions only because, just as these latter, it traditionally accords to the executive an extremely broad area of nonjusticiability in FRs matters.

69 See e.g. Bond v. United States, 564 US 211 (2011) (Bond I). 
agreement or the process of treaty-making) which in some cases may lead to the invalidation of the law implementing a treaty, but also the use of constitutional general principles. These latter include both the respect of constitutional rights, often interpreted in the light of international law, and general clauses and standards such as reasonableness and proportionality. Major examples pointing to this direction may be drawn from German, ${ }^{70}$ Italian $^{71}$ and US case law, as well as from the European Court of Justice (ECJ). ${ }^{72}$

Importantly, US federal courts applied proportionality/balancing techniques in issuing (or in staying) preliminary injunctions barring the enforcement of President Trump's 'travel bans'..$^{73}$ This application is particularly significant, especially when compared to the traditional 'plenary power doctrine'. ${ }^{74}$ Similar developments may be observed in the case law on the treatment of enemy combatants in the 'war on terror'. ${ }^{75}$

In this context, and even though it did not resort to balancing techniques, the decision of the OVG Münster is particularly interesting. Indeed, based on a typical result-oriented norm - the obligation to protect the life and physical

70 See again Franck, Political Questions/Judicial Answers, pp. 107-25; Peters, 'Military Operations Abroad under the German Basic Law'.

${ }^{71}$ See decisions nos. 54/1979, 132/1985, 128/1987, 223/1996, 238/2014 of the Constitutional court. Further, with the decision No. $135 / 1963$, the court declared unconstitutional a decree precluding any action against decisions of the Minister of Justice in respect of seizure of goods belonging to foreign States.

$7^{2}$ See Case 93/78, Lothar Mattheus v. Doego Fruchtimport und Tiefkühlkost eG [1978] ECR 2203; Case 191/82, EEC Seed Crushers' and Oil Processors' Federation (FEDIOL) v. Commission of the European Communities [1983] ECR 2913; Case C-70/94, Fritz Werner Industrie-Ausrüstungen GmbH v. Federal Republic of Germany [1995] ECR I-0318958; Case C-120/94, Commission of the European Communities v. Hellenic Republic [1994] ECR I-03037; Joined Cases C-402/05 P and C-415/05 P, Yassin Abdullah Kadi and Al Barakaat International Foundation v. Council of the European Union and Commission of the European Communities [2008] I-6351; Case C-104/16 P, Council of the European Union v. Front populaire pour la libération de la saguia-el-hamra et du rio de oro (Front Polisario) [2016] ECLI:EU:C:2016:973. See Panos Koutrakos, 'Judicial Review in the EU's Common Foreign and Security Policy' (2018) 67 International \& Comparative Law Quarterly 1.

73 See e.g. Int'l Refugee Assistance Project, 582 US (2017), and the en banc decision of the Court of Appeals for the Fourth Circuit Vilar, 729 F.3d 62 (30 August 2013). See Desiree C. Schmitt, 'The Doctrine of Consular Nonreviewability in the Travel Ban Cases: Kerry v. Din Revisited' (2018) 33 Georgetown Immigration Law Journal 55. See also Trump v. Hawaii, 585 US (2018) which, although upholding a later version of the travel ban, emphasizing deference to the executive, still applied a rational basis review.

74 Justifying the 'constitutional exceptionalism' of US immigration law with reference to the connection between the admission and removal of foreigners and 'basic aspects of national sovereignty, more particularly ... foreign relations and the national security in immigration policies': see Matthew J. Lindsay, 'Immigration, Sovereignty, and the Constitution of Foreignness' (2012-13) 45 Connecticut Law Review 743.

75 See again the 'Guantanamo cases' (n. 61). 
integrity deriving from article $2(2)$ of the German Basic Law - it held that, as the legality of the US strikes was doubtful under international humanitarian law, the right to life of the claimants might have been violated. This triggered two obligations of the German authorities: (1) to make sure, on the basis of the legal assessment of the court, whether the practice of US strikes in Yemen region is in conformity with international law as it stands - to the extent that the German territory is involved; and ( 2 ) to take measures deemed appropriate in order to work towards compliance with international law.

Another interesting instance is the Urgenda saga, where Dutch courts ruled that the government owes a duty of care to its citizens to provide protection against the risks posed by climate change. ${ }^{6}$ Based on general principles of domestic civil law, reinterpreted in the light of the UN and EU climate agreements, along with international law principles and climate science, Dutch courts ordered the government to revise its policies and ensure that by the end of 2020 carbon dioxide emissions are reduced by 25 percent compared to 1990 levels, that is, more than that initially planned by the government in the context of the Paris agreement. Also in this case, based on result-oriented domestic and international norms (principle of duty of care plus reduction of greenhouse emissions), judicial bodies reviewed the legality of measures adopted by political branches, and indicated the way to manage ('administer') a given issue, namely climate change. This also implies that the court co-determined, at least indirectly, the concrete implementation of the Netherlands' international obligations. Although not immediately connected with IRs stricto sensu, the Urgenda saga is highly significant to our purposes: by judicially restricting the executive's discretion on the concrete implementation of international obligations, Dutch courts potentially set an important precedent also in fields different from climate justice, as they codetermined the possible options on the design of foreign policy.

A third exemplary case is the 2019 SADC Tribunal judgment of the South African Constitutional Court, ${ }^{77}$ concerning the decision of the Southern

${ }^{6}$ Urgenda Foundation, case C/o9/456689/HA ZA 13-1396, 24 June 2015; Urgenda, Case 200.178.245/01, 9 October 2018; Urgenda, Case 19/00135, 20 December 2019. See Suryapratim Roy, 'Urgenda II and Its Discontents' (2019) 13 Carbon \& Climate Law Review 130; and Otto Spijkers, 'Pursuing Climate Justice through Public Interest Litigation: the Urgenda Case', in Völkerrechtsblog, April 29, 2020, https://voelkerrechtsblog.org/pursuingclimate-justice-through-public-interest-litigation-the-urgenda-case/, accessed September zo, 2020 .

77 Law Society of South Africa and Others v. President of the Republic of South Africa and Others (CCT67/18) [2018] ZACC 51; 2019 (3) BCLR 329 (CC), https://collections.concourt.org.za/h andle/20.500.12144/34610. See Riaan Eksteen, The Role of the Highest Courts of the United States of America and South Africa, and the European Court of Justice in Foreign Affairs (The 
African Development Community (SADC) heads of State and Government to remove the right of individual access to the SADC Tribunal. Approached by the Law Society of South Africa, the Court found that the executive's participation in the 'decision-making process and his own decision to suspend the operations' of the Tribunal to be unconstitutional, unlawful and irrational..$^{8}$ The judgment also found that the signing of the 2014 Protocol was unconstitutional, unlawful and irrational and, as a result, ordered the President to withdraw his signature, greatly restricting the executive's discretion. Importantly, the Court based its reasoning on the fact that the 2014 Protocol denied citizens of South Africa and other SADC countries the access to justice at a regional level, despite the fact that such individual access is not per se imposed by any international law obligation, not even at regional level. ${ }^{79}$

A final remarkable example is the judgment C-252/19 of the Colombian constitutional court. ${ }^{8 \circ}$ Evaluating the compatibility with the domestic constitution of a bilateral investment treaty (BIT) signed with France, the court declared it 'conditionally constitutional', that is, only under specific conditions. Turning away from previous approaches, ${ }^{81}$ the Colombian court imposed to the executive branch the negotiation and adoption of a joint interpretive note, concerning the meaning to attribute to several clauses of the BIT. Also in this case, a domestic court did not merely review the legality of executive's conduct in FRs - namely, the exercise of treaty-making power but also imposed to take specific measures and, therefore, actively participated in the concrete management/administration of Colombia's FRs.

In other cases, judicial review of FRs conducts has come to impose participatory/procedural rights of parliaments or other actors, even when relevant domestic law does not explicitly provide for or is unclear on that point. ${ }^{82}$ In this

Hague: Asser Press, 2019), pp. 305-11; and Tladi, 'A Constitution Made for Mandela, a Constitutional Jurisprudence Developed for Zuma', this volume.

78 Law Society of South Africa and Others v. President of the Republic of South Africa and Others, para. 97.

79 See again Tladi, 'A Constitution Made for Mandela, a Constitutional Jurisprudence Developed for Zuma', this volume.

8o C-252/19, expediente LAT-445, www.corteconstitucional.gov.corelatoria/2019/c-252-19.htm, accessed September 30, 2020. See Gustavo Prieto, "The Colombian Constitutional Court Judgment C-252/19: A New Frontier for Reform in International Investment Law', EJIL: Talk!, July 29, 2019, www.ejiltalk.org/the-colombian-constitutional-court-judgment-c-252-19-a-newfrontier-for-reform-in-international-investment-law/, accessed September 30, 2020.

$81 \quad$ See e.g. C-358/96 and C-379/96.

82 See Pierre-Hugues Verdier and Mila Versteeg, 'Separation of Powers, Treaty-Making, and Treaty Withdrawal: A Global Survey', in Curtis A. Bradley (ed.), Oxford Handbook of Comparative Foreign Relations Law (Oxford: Oxford University Press, 2019), pp. 136-55, showing that there is a clear trend reflecting increased involvement of both parliamentary 
regard, however, there are still significant differences between the US and other - notably European - jurisdictions. Undeniably, a field where the US political question doctrine remains almost untouchable concerns the choice on the way to internally implement or to withdraw from international agreements. $^{83}$

On the other side of the ocean, the UK Supreme Court recently held that the government was required to obtain authorization from parliament before it could initiate withdrawal from the EU. ${ }^{8}$ Although British scholarship has not reached a consensus as to whether the decision is in continuity with UK constitutional tradition, ${ }^{85}$ it was mainly based on the principle of parliamentary sovereignty. However, it also relied on the principle that democratic consent mediated by (constitutional) law is necessary to take the most fundamental FRs decisions affecting the rights of British citizens, and, more generally, involving 'fundamental change in the constitutional arrangements'. The UK Supreme Court seemed thus to overcome the 1971 ruling concerning the British accession to the European Community, stating that it was beyond the jurisdiction of the courts to perform a judicial review on Parliament's rightful exercise of its powers. ${ }^{86}$ Even more importantly, following such judgment the British parliament passed legislation empowering the Prime Minister to give to the EU Council the notice for starting negotiations for the UK's withdrawal from the $\mathrm{EU}^{87}$ and requiring Parliamentary approval of the outcome of the government's negotiations with the EU under article 50 (2) of the TEU. ${ }^{88}$ It is therefore fair to say that, although it cannot be regarded as a direct judicialization of FRs, the high instability due to the parliamentary involvement in the Brexit negotiations is also and at least indirectly a result of that decision, that is, that of the imposition by a court of a procedural requirement on the management of a FRs issue.

and judicial branches in treaty-making in constitutional systems; and Jean Galbraith, 'From Scope to Process', this volume.

83 See Goldwater v. Carter, 444 US 996 (1979); Made in the USA Foundation, 56 F. Supp.2d 1226 (ND Ala 1999) which had reached the merits of the case, thus excluding that the case presented a nonjusticiable political question.

$8_{4}$ R (Miller) v. Secretary of State for Exiting the European Union [2017] UKSC 5, [2018] AC 61. See generally Mark Elliot, Jack Williams and Alison L. Young (eds.), The UK Constitution after Miller (Oxford: Hart, 2018).

85 See David Feldman, 'Pulling a Trigger or Starting a Journey? Brexit in the Supreme Court' (2017) 76 The Cambridge Law Journal 217; Gavin Philippson, 'Brexit, Prerogative and the Courts: Why Did political Constitutionalists Support the Government Side in Miller?' (2017) 36 University of Queensland Law Journal 311; Campbell McLachlan, 'The Foreign Relations Power in the Supreme Court' (2018) 134 Law Quarterly Review 380.

86 Blackburn v. Attorney General [1971] 2 All ER 1380.

87 European Union (Notification of Withdrawal) Act 2017.

88 European Union (Withdrawal) Act 2018. 
Similar decisions were taken by the Irish Supreme Court, ruling that any new provision amending the $\mathrm{EC} / \mathrm{EU}$ treaties which alters 'the essential scope or objectives' of the $\mathrm{EC} / \mathrm{EU}$ requires the intervention of the people to be constitutionally valid; ${ }^{89}$ and the BVerfG which, in its Lisbon treaty ruling, alluded to the possibility that the German people as constituent power adheres to a future European federal state through referendum, despite the fact that such institute is not foreseen by the German Basic Law. ${ }^{90}$ In this regard, it worth recalling that some continental scholars have even taken a step further, looking for legal bases to entitle foreign subjects to challenge a State's foreign policy. ${ }^{91}$

Outside the European context, the major example can probably be found in South Africa. In Democratic Alliance v. Minister of International Relations and Cooperation, ${ }^{9}$ the High Court of Gauteng was faced with a question similar to that decided by the UK Supreme Court in Miller, that is, the executive's withdrawal from the Rome Statute, an international treaty ratified and domesticated by the parliament, without prior parliamentary approval. Although the question is not directly addressed by the South African Constitution, in 2017 the Court, stressing the importance of public participation when withdrawing from treaties, ${ }^{93}$ held that Section 231(2) of the Constitution, requiring parliamentary approval for treaties subject to ratification, also requires by implication parliamentary consent to withdraw from such treaties. Therefore, the notice of withdrawal was unconstitutional and invalid.

More generally, some scholars suggest that FRs issues are best addressed by judicial bodies through traditional balancing/proportionality standards of review. ${ }^{94}$ Obviously, in deciding which values/rights to balance, and the 'weight' to give to each of them, courts inevitably exercise some discretion, which cannot

89

BVerfGE 123, 267-Lissabon, paras. 217, 228. See however art. 146, hinting to the replacement of the Basic Law by a 'constitution freely adopted by the German people'.

91 See e.g. Umberto Allegretti, 'Costituzione e politica estera: punti preliminary' (1990) 4 Pace, diritti dell'uomo, diritti dei popoli 31.

92 Democratic Alliance v. Minister of International Relations and Cooperation and Others 2017 (3) SA 212 (GP) ('Withdrawal judgment'), www.saflii.org/za/cases/ZAGPPHC/2017/53.pdf. See Hannah Woolaver, 'State Engagement with Treaties: Interactions between International and Domestic Law', in Curtis A. Bradley (ed.), Oxford Handbook of Comparative Foreign Relations Law (Oxford: Oxford University Press, 2019), pp. 431 at 440-42 (comparing the UK Supreme Court Miller judgment); and Tladi, 'A Constitution Made for Mandela, a Constitutional Jurisprudence Developed for Zuma', this volume.

93 Democratic Alliance v. Minister of International Relations and Cooperation and Others, paras. $61-63$.

94 See e.g. Daniele Amoroso, "Judicial Abdication in Foreign Affairs and the Effectiveness of International Law' (2015) 14 Chinese Journal of International Law 99 (and the literature recalled). 
but impact on a State's FRs. Also from this perspective, they might increasingly participate in the management/administration of FRs.

\section{B Interaction Norms}

This subsection looks at the trends concerning the interaction norms, implemented and/or developed to manage interactions with other jurisdictions or legal systems affecting FRs. Similarly to the review norms, courts may base their rulings on either procedural or substantive grounds, but such subcategorization can be even more blurred.

Such norms include the application of '(foreign) act of State' and sovereign immunity doctrines - limiting the circumstances under which courts examine the validity of foreign governments acts and the responsibility of sovereign actors - as well as other doctrines of judicial abstention (international comity, forum non conveniens, margin-of-appreciation, subsidiarity, Solange, controlimiti, etc.) preventing judges from evaluating the merits of a claim or grant recognition/enforcement of outer legal sources.

In particular, in common law jurisdictions - especially in the US - courts seem to explicitly take into consideration, next to strictly legal elements, lato sensu political elements. ${ }^{95}$ While such attitude contributes to make their decisions more understandable, it also affects their capacity to set clear and foreseeable standards, and has been generally criticized for its unpredictability. ${ }^{96}$ In European jurisdictions, where the choice-of-law rules are generally seen as less flexible and more predictable, ${ }^{97}$ such elements are hidden in the folds, so to say, of legally 'pure' argumentations.

This attitude is quite apparent in the evolution of the US 'act of State' doctrine, whose scope ${ }^{98}$ has been narrowed since 1990 by the Supreme Court, ${ }^{99}$ limiting the case-by-case balancing in deciding whether to apply it or not. ${ }^{100}$ More generally,

95 See Timothy A. O. Endicott, 'International Meanings: Comity in Fundamental Rights Adjudication' (2001) 92 International Journal of Refugee Studies 280; and, more generally, part VI of Curtis A. Bradley (ed.), Oxford Handbook of Comparative Foreign Relations Law (Oxford: Oxford University Press, 2019), pp. 625-732.

${ }^{6}$ See Dodge, 'International Comity in Comparative Perspective'.

97 See Regulation (EC) No. 864/2007 of 11 July 2007 on the law applicable to non-contractual obligations (Rome II), OJ 2007 No. L199, 31 July 2007, pp. 40 ff.; Regulation (EU) 1215/2012 of 12 December 2012 on jurisdiction and the recognition and enforcement of judgments in civil and commercial matters, OJ 2012 No. L351.

$9^{8}$ See Banco Nacional de Cuba v. Sabbatino, 376 US 398 (1964).

99 Kirckpatrick \& Co v. Environmental Tectonics Corp, 493 US 400 (1990).

100 However, subsequent federal jurisprudence was not particularly consistent: see Curtis A. Bradley, Ashley S. Deeks and Jack L. Goldsmith, Foreign Relations Law. Cases ङ Materials (New York: Wolters Kluwer, 2020), pp. 84-102. 
US courts increasingly adopt reasonableness standards in deciding whether to extend the reach of domestic law or not. ${ }^{101}$ Importantly, this 'prescriptive comity', consisting in the respect sovereign nations afford each other by limiting the reach of their laws, does not totally coincide with the 'judicial comity', whereby judges decline to exercise jurisdiction over matters more appropriately adjudged elsewhere, as it happens in the forum non conveniens doctrine. ${ }^{102}$ Similarly, in the field of extraterritorial jurisdiction, it is possible to observe an - apparently paradoxical double movement toward global coordination: while US courts seem to progressively reduce the extraterritorial reach of their jurisdiction when the legal text do not explicitly provide otherwise, ${ }^{103}$ the European multilevel system seems to progressively expand its reach. ${ }^{104}$

Here, two points are worth underlining. First, in many instances courts, especially in the US, take into consideration the foreign policy dimension in order to decide a case or to interpret relevant laws, often against the positions of executive branches. This is quite apparent in the Alien Tort Statute (ATS) case law, ${ }^{105}$ where the Court explicitly or implicitly decided the cases based on its own assessment of how to avoid diplomatic frictions. Second, reasonableness and proportionality may be applied not only to evaluate a FRs act as such, but also to extend or narrow the reach of a court's own legal system. Consequently, substantive evaluations affect procedural decisions, which only apparently do not concern the merits of a case. Indeed, in the context of decisions related to interaction norms, there is often a silent shift towards substantive standards of review, hidden in the fabric of procedural rulings. ${ }^{106}$

This is quite apparent when courts, in deciding whether to extend their jurisdiction extraterritorially or not, refer to the respect of human rights and/or justice in the system which would be competent. For example, before the ECJ judgment Owusu ruled that Regulation (EC) 44/2001 prevented its application, this was the case for the British forum non conveniens doctrine. In

101 For the related case law see generally Breyer, The Court and the World, pp. 89-164.

102 See F. Hoffman-La Roche Ltd. v. Empagran S.A., 542 US 155 (2004).

103 See Aramco, 499 US 244 (1991); Morrison, 561 US 247 (2010); Kiobel, 569 US 108 (2013); Vilar, 729 F.3d 62 (August 30, 2013).

104 See e.g. EctHR, Al-Skeini 6 Others v. UK (Appl. No. 55721/o7), Judgment (Grand Chamber), July 7, 2011, www.rulac.org/assets/downloads/CASE_OF_AL-SKEINI_AND_OTHERS_v._ THE_UNITED_KINGDOM.pdf; Jaloud v. The Netherlands (Appl. No. 47708/08), Judgment (Grand Chamber), November 20, 2014, http:/hudoc.echr.coe.int/eng?i=001-1483 67; and the ECJ judgment Owusu, Case C-281/o2, Andrew Owusu v. N.B. Jackson, trading as 'Villa Holidays Bal-Inn Villas' (et al.) [2005] ECR I-01383, and their effects on the legal systems of Member States (especially the UK).

105 Sosa, 542 US 692 (2004); Kiobel, 569 US 108 (2013); Jesner v. Arab Bank, PLC, 584 US (2018).

106 See Galbraith, 'From Scope to Process', in this volume. 
determining 'the more appropriate forum', British courts took into account the interests of the parties and the nature of the subject matter, and made a determination as to whether another forum was more appropriate than England. Further, they inquired as to whether 'substantive justice' would be achieved in that other forum. This second part distinguished the English test from the US test, where 'justice' is not such an explicit element. ${ }^{107}$ Similar considerations influenced the Pinochet case, where the House of Lords held that (1) allegations of torture and hostage taking 'pierced the veil' of the personal jurisdictional immunity granted of Heads of State, codified in articles 28, 29 and 31 of the Vienna Convention of Diplomatic Relations (and in part II of the 1978 State Immunity Act); (2) the Crown act of state doctrine was inapplicable, as Parliament, by enacting section 134(1) of the 1988 Criminal Justice Act defining torture and section 1(1) of the 1982 Taking of Hostages Act, had shown that the conduct with which Pinochet was charged was a justiciable matter before the English courts. ${ }^{108}$ More recently, similar arguments were the basis for the Belhaj decision, ${ }^{109}$ holding that the UK government could not rely on sovereign immunity and foreign act of state to escape claims in the two cases alleging UK involvement in breaches of human rights by foreign governments in Libya. ${ }^{110}$

In an opposite and equal direction, domestic courts increasingly use balancing techniques, reasonableness and human rights in granting recognition or enforcement to foreign sources into domestic systems, or in granting selfexecuting status to international law norms. This field is notoriously explored in the European continental scholarship, as a consequence of the EU integration process. EU member States, Germany and Italy in particular, have developed similar - though not coincident - doctrines of constitutional tolerance/resistance (Solange, controlimiti), which accord or deny the 'entrance' of external legal sources under certain circumstances, and have contributed to

107 See in particular Lubbe [2000] 4 All ER 268 (UKHL).

108 R v. Bow Street Metropolitan Stipendiary Magistrate, ex parte Pinochet Ugarte [1998] 2 WLR 827 (HL 1999).

109 Belhaj \& Rahmatullah (No 1) v. Straw \& Ors [2017] UKSC 3. See again Bjorge and Miles, 'Crown and Foreign Acts of State before English Courts'.

110 Outside Europe, one may refer here again to the judgment of the South African Constitutional Court SADC Tribunal (n. 77), para. 11. Insofar as its reasoning is based on the denial to citizens of South Africa and other SADC countries of the right to access to a regional tribunal, the judgment seemed to imply that the executive, when acting in FRs, should do so in a manner that protects fundamental rights extraterritorially: see Tladi, "A Constitution Made for Mandela, a Constitutional Jurisprudence Developed for Zuma', this volume. 
the reflexive evolution of the EU system towards greater political integration and respect of fundamental rights.

These models of constitutional tolerance/resistance/jurisgeneration are increasingly invoked and applied outside the intra-EU context, as a general template to manage inter-systemic collisions. ${ }^{111}$ The most famous example probably remains the Kadi saga, comprising several decisions whereby the ECJ annulled EU Regulations implementing UN Security Council resolutions imposing restrictive measures directed against persons and entities associated with Al-Qaeda, for the violation of the affected persons' procedural rights, such as the right to be heard and the requirement for an adversarial process. As a result, a source of binding international law was denied entrance and implementation into the EU legal system. ${ }^{112}$

A significant example of this model and its potential risks is judgment no. $238 / 2014$ of the Italian constitutional court. Although it is not possible to provide the full procedural background, this ruling held that the norm of customary international law (CIL) concerning the jurisdictional immunity of States for acta iure imperii, as ascertained by the ICJ in $2012-{ }^{113}$ was incompatible with the 'supreme principles' of the constitution, when applied to exclude Italian civil jurisdiction for war crimes committed by the Third Reich. ${ }^{114}$ In particular, the Italian court recognized the ICJ's monopoly over the interpretation of CIL, proclaiming its incompetence to reassess the existence of the rule on the State immunity, and how it relates to the right to jurisdictional remedy. Secondly, claiming to adopt a balancing approach, ${ }^{115}$ it weighted the values that - in its opinion - were at stake: the total

${ }^{111}$ See Nikolaos Lavranos, "The Solange-Method as a Tool for Regulating Competing Jurisdictions among International Courts and Tribunals' (2008) 30 Loyola of Los Angeles International and Comparative Law Review 275 (seeing the Solange method as a genus of the species 'judicial comity').

112 See in particular Joined Cases C-584/10 P, C-593/10 P and C-595/10 P, European Commission and Others v. Yassin Abdullah Kadi [2013] ECLI:EU:C:2013:518. See Matej Avbelj, Filippo Fontanelli and Giuseppe Martinico (eds.), Kadi on Trial. A Multifaceted Analysis of the Kadi Trial (London: Routledge, 2014). A similar case, with the same result, was decided in the UK in HM Treasury v. Ahmed o others [2010] UKSC 2.

113 Jurisdictional Immunities of the State, 3 February 2012.

114 For a similar case in Greece see Areios Pagos, Prefecture of Voiotia v. Fed Republic of Germany, 11/2000 (awarding damages against Germany for war crimes during World War II).

115 See ItCC judgment No. 238/2014, paras. 3.1-3.5, para. 3.1: 'It is indeed possible to review the [constitutional] compatibility even when both norms - as in the case at issue - have constitutional status, since balancing is one of the ordinary tasks that this Court is asked to undertake in all cases within its competence.' One may question whether the subsequent reasoning constitutes an actual exercise of judicial balancing but what matters to our purposes is the fact that balancing discourse, based on principled legal norms, facilitates judicial intervention in the management of FRs. 
ineffectiveness of the right to an effective jurisdictional remedy, under articles 24 of the Italian Constitution and 6 ECHR; and the State immunity recognized by international law, in this case shielding the commission of war crimes. Thirdly, it denied the 'entrance' of the CIL norm into the domestic system, thus preventing ordinary courts from implementing it.

Importantly, and first, the court at least formally accorded deference to the ICJ. As some scholars argued, ${ }^{116}$ the court could have autonomously reassessed the scope of the CIL norm on State immunity, but rather claimed not to be allowed to do so. However, in this case 'judicial comity' did not lead to 'legal comity', ${ }^{117}$ as it provoked a diplomatic deadlock. Secondly, the court took a position clearly in conflict with the Italian parliament and government. ${ }^{118}$ Indeed, in its balancing it did not take into account, or did not give much weight, to other possibly involved values, for example the "peace among nations' and the interest to friendly relationships among sovereign entities (article 11). Regardless of its legal form, this relatively discretional choice had a political impact. Thirdly, the court explicitly had a 'iurisgenerative' intent, that is, the purpose of inducing changes in international law, namely the scope of the State immunity norm, ${ }^{119}$ and also aimed to compel the Italian government to promote further negotiations with Germany. Fourthly, in order to support its argument and the final outcome, the court explicitly relied on the ECJ's Kadi case law, thus trying to present its decision so as to be coherent with a broader 'transnational' judicial consensus. ${ }^{20}$ Finally, the subsequent practice of lower courts has proved crucial in somehow managing and deescalating the resulting diplomatic deadlock, either when they formulated settlement proposals with the German government; ${ }^{121}$ or when they found that

116 Giovanni Boggero, 'The Legal Implications of Sentenza No. 238/2014 by Italy's Constitutional Court for Italian Municipal Judges: Is Overcoming the "Triepelian Approach" Possible?' (2016) 76 Heidelberg Joumal of International Law 203.

117 See D’Alterio, 'From Judicial Comity to Legal Comity'.

118 Aiming at avoiding diplomatic friction with Germany, in 2013 the Italian parliament added a provision to the law ratifying the 2004 New York Convention on Jurisdictional Immunities of States, excluding the Italian jurisdiction for war crimes committed by the Third Reich, even for pending proceedings. The Court also declared such provision unconstitutional and, in this sense, judgment No. $238 / 2014$ could also be analyzed from the perspective of the 'review norms'.

119 For a critical assessment see Raffaela Kunz, "The Italian Constitutional Court and “Constructive Contestation”: A Miscarried Attempt?' (2016) 14 Journal of International Criminal Justice 621.

120 See para. 3.4.

121 See Trib Florence, Simoncioni, Order March 23, 2015; and Trib Florence, Simoncioni, No. 2469, July 6, 2015. On this point see Daniele Amoroso, 'Italy', in Fulvio Maria Palombino (ed.), Duelling for Supremacy. International Law vs. National Fundamental Principles (Cambridge: Cambridge University Press, 2019), pp. 186-92. 
the rule on State immunity still barred the exercise of executive jurisdiction, thus avoiding the seizure of German assets in Italy. ${ }^{122}$

From a more general perspective, this example is significant, as it concerns the development by a domestic court of norms regulating the relationships between an external legal system (in this case, CIL) with the domestic one. Further, it demonstrates that, while it is generally true that the "judge judging the judge" activity heavily depends on the political influence and diplomatic relations between systems', ${ }^{123}$ in many instances judicial rulings may run contrary to otherwise friendly relations and the reciprocal trust.

The scenario arisen from the judgment no. $238 / 2014$ is not an isolated case but, as courts increasingly 'administer' FRs, reflects a potentially recurring scenario. Here again, and although it did not involve any interaction between judicial bodies, the decision of the OVG Münster on the Ramstein base provides a significant example. Indeed, insofar as it raised doubts on the legality of the strikes conducted through the Ramstein base by the US government, and imposed the German government to take appropriate measures in that regard, such decision generated also interaction norms, affecting the coordination/cooperation with other systems in FRs matters. This, however, restricted greatly the diplomatic room of maneuver of Germany, and seem to have produced a diplomatic deadlock with the US, a key strategic ally. ${ }^{124}$

In yet other cases, political influence and economic interests, as well as power grab considerations, ${ }^{125}$ rather than 'humanity', might play a more direct role into the development of interaction norms. This may be the case, for example, of the use of self-executing doctrines by the US Supreme Court towards the rulings of the ICJ, ${ }^{126}$ and by the ECJ in the field of GATT, WTO

122 Ordinary courts applied art. 39(1) of the 1957 European Convention for the Peaceful Settlement of Disputes, not involved in the decision of the ItCC. See however the judgment of the Italian Supreme Court Cass, No. 21995, June 25, 2019, allowing executive actions against a German state-owned company, brought by Greek plaintiffs for credits concerning Third Reich's war crimes, to proceed before Italian courts.

123 D'Alterio, 'Judicial Regulation in the Global Space', p. 317.

124 See again Aust, 'US-Drohneneinsätze', pp. 307 ff.

125 See Federico G. Thea, 'The Role of Judges in Political Struggles' (2012) 2 Queen Mary Law Journal 57; and, more generally, Richard A. Posner, How Judges Think (Cambridge-London: Harvard University Press, 2008).

126 Medellin v. Texas, 552 US 491 (2008), a case in many ways similar to judgment No. 238/2014 of the ItCC, as it held that the Avena judgment of the ICJ was not enforceable as domestic law, thus letting the execution of a death penalty against a Mexican national. Also in this case, the Supreme Court took a stance opposite to that of President Bush administration, and created significant diplomatic frictions with Mexico. 
and international economic agreements. ${ }^{127}$ Similarly, US courts restricted the extraterritorial reach mainly in the field of human rights protection, ${ }^{128}$ but narrowed it only slightly as regards its instruments of (direct or indirect) government of global economy, often with the result to shield US companies from lawsuits brought by foreign nationals. ${ }^{129}$ In these instances, domestic courts, in denying the direct effect of international binding norms, seem more concerned with preserving their domestic authority as holders of the 'final say', or with guaranteeing domestic political and/or economic interests.

\section{CONCLUSION: THE ADMINISTRATIVE CONCEPTION OF FRL, ITS ‘TRANSNATIONALITY’ AND POTENTIAL RISKS}

The necessarily a-systematic survey conducted above, based on the GAL analytical framework, seems to provide some answers to the persisting struggles of FRL scholarship. First, the GAL approach confirms the necessity to look at FRL in functional terms. At a time when the divide between foreign and domestic affairs has become almost impalpable, the (study of the) law of FRs cannot be limited to the traditional areas of treaty-making; international and supranational integration; and use of military force. To have a realistic understanding of the law/FRs relationship, the scope of FRL (and its scholarship) must include the legal fields functionally affecting FRs. Although admittedly in the age of globalization FRs are virtually everywhere, the GAL approach provides reasons to expand the scope of FRL, so as to include at least

127 See ECJ, Joined Cases C-21-24/72, International Fruit Company NV and others v. Produktschap voor Groenten en Fruit [1972] ECR o1219; Case C-280/93, Germany v. Council [1994] ECR I-04973; Case C-149/96, Portugal v. Council, [1999] ECR I-o8395; Case C-377/02, Léon Van Parys NV v. Belgisch Interventie- en Restitutiebureau (BIRB) [2005] ECR I-01465; Joined Cases C-300/98 and C-392/98, Parfums Dior and Assco Gerüste [2000] ECR I-11307. See also the judgment in Case C-284/16, Slowakische Republik v. Achmea BV, [2018] ECLI:EU:C:2018:158, holding that the arbitration clause contained in art. 8 of the 1991 Netherlands-Slovakia BIT had an adverse effect on the autonomy of EU law, and was therefore incompatible with it.

${ }_{128}$ See again the ATS case law (n. 105).

129 See e.g. the 2010 Dodd-Frank Act: While its repressive provisions have a broad territorial reach (they can be applied each time there is a "foreseeable substantial effect within the United States'), Liu v. Siemens AG (no 13-cv-4385, 2014 WL 3953672 (2d Cir. August 14 2014)) held that the anti-retaliation provisions protecting whistle-blowers do not apply extraterritorially, even for companies listed on the US stock exchange. See also RJR Nabisco, 579 US (2016) holding that the Racketeer Influenced and Corrupt Organizations Act has certain extraterritorial applications, but plaintiffs must prove injuries within the US for the act to apply; and Jam, 586 US (2019), where the US Supreme Court, denied absolute immunity under the International Organizations Immunity Act to the International Finance Corporation, part of the World Bank group. 
all the legal fields that somehow separate the internal from the external and mediate the inward reception of international law into the domestic legal system. ${ }^{130}$ In this regard, looking at FRL through the lenses of GAL offers another conception of (the function of) FRL in the context of legal-political globalization: the administrative one. Such conception captures the idea that the sources of FRL - be they domestic or international - provide relevant institutional actors with concrete goals and results to accomplish in the context of FRs, as well as substantive and procedural standards to 'manage' FRs, whose respect can be in turn reviewed by judicial bodies.

The functional understanding of FRL makes apparent another key element brought out by the GAL approach: the role of 'global regulators' of courts, in a domain where their influence is still underestimated. ${ }^{131}$ The expansion of the judicial reach in FRs is not just quantitative, as more and more FRs questions are adjudicated by courts on the merits; but also qualitative, as judicial rulings affect the concrete management/'administration' of FRs. Courts - either voluntarily or involuntarily, either directly or indirectly - increasingly participate in the exercise of FRP, as they contribute to set or change the legal patters that the political branches must follow, also prospectively. This holds true even when courts adhere to the position of political branches: as courts step into the FRs arena, for analytical purposes it does not change much whether their assessments coincide to that of the executives and parliaments or not. For this reason, in highlighting the role played of courts, the GAL approach could also strengthen their self-awareness and responsiveness, just as for other GABs.

The analytical tools provided by GAL proved also useful to assess the emerging 'transnationality' in FRL, in two respects at least. Firstly, in adjudicating FRs questions judicial bodies often apply a sort of 'patchwork' of domestic and international legal sources. ${ }^{132}$ Secondly, courts seem increasingly to develop comparable and/or equivalent argumentative models and standards of review, sometimes even explicitly recognizing reciprocal influence. ${ }^{133}$ However, the degree of formalization of such "common language' is probably fated to remain underdeveloped, when compared to other functionally differentiated fields which constitute the usual focus of GAL studies. Indeed, next to other factors which make judicial networks less formalized than others, in FRs matters judiciaries are torn between, on the

130 See Aust and Kleinlein, 'Introduction', this volume.

${ }^{131}$ See however in the most recent literature Eksteen, The Role of the Highest Courts, assessing the role of courts applying foreign policy analysis.

132 See e.g., the Urgenda Foundation, District Court of the Hague, 24 June 2015, paras. 4.35-4.86 and the Ramstein decision OVG NRW 4 A $1361 / 15$, spec. pp. $52 \mathrm{ff}$.

133 See, e.g., the ItCC judgment No. 238/2014, para. 3.4, recalling the ECJ's Kadi decisions. 
one hand, [their] loyalty to the international and national rule of law and, on the other, [their] allegiance to national or organisational interests. ${ }^{134}$

This point leads to a final consideration. The survey showed that the expansion of the judicial reach on FRs questions often ends up in further obstacles to the coordination of conflicting systems and to the ordering of global governance. Even the use of human rights or other substantive standards can lead to greater disorder, especially because courts' decisions highly differ as regards their hierarchization. The administrativization of FRs a complex phenomenon driven, among other factors, by the greater relevance to the legal position of the individual, the spread of (constitutional) resultoriented norms, and a procedural turn in FRL - does not always imply greater coordination among systems, but can rather bring more disorder, conflict and unpredictability. The Miller judgment of the UK Supreme Court, the ItCC judgment no. 238/2014 and the ruling of the OVG Münster on the Ramstein base - the very case with which we opened this chapter - are glaring examples of the risks linked to this trend. More generally, this consideration puts somehow into question the normative aspirations of GAL, insofar as it advocates for the expansion of 'administrative' norms and judicial control on the exercise of power in transnational arenas, with the goal to decrease conflicts and inconsistencies among involved actors/systems, and increase their legitimacy. Although a critical assessment of such normative aspirations lies outside the scope this chapter, the administrativization of FRs, and the role played by courts in that context, constitute a hard test for the capacity of the GAL project - not only to describe, but also - to order the structures of global governance, and opens new venues for further research in the vast field of the relationship between law, FRs and global governance.

134 Giegerich, 'Foreign Relations Law', p. 186. See also Benvenisti and Downs, Between Fragmentation and Democracy, pp. 145-48. 